\title{
Analysis of Borrelia species associated with Lyme disease by rRNA gene restriction fragment length polymorphism
}

\author{
Masahito Fukunaga, ${ }^{1 *}$ Masako Sohnaka $^{1}$ and Yasutake Yanaginara ${ }^{2}$ \\ ${ }^{1}$ Faculty of Pharmacy and Pharmaceutical Sciences, University of Fukuyama, Hiroshima 729-02, Japan \\ ${ }^{2}$ Department of Microbiology, University of Shizuoka, Yada, Shizuoka 422, Japan
}

(Received 6 October 1992; revised 3 February 1993; accepted 9 February 1993)

\begin{abstract}
We investigated the usefulness of rRNA gene restriction fragment length polymorphism (RFLP) for grouping of the Borrelia isolates associated with Lyme disease or from ixodid ticks. Genomic DNA was digested with a restriction enzyme, blotted and hybridized with an $r r l$ (23S rRNA) gene probe. The sizes of the restriction bands showed a good correlation with the genotypes recently proposed, and Borrelia isolates of diverse geographic origin formed four distinct DNA groups. Group I included all of the USA isolates and some European isolates; group II contained European isolates and Asian isolates; group III comprised European and Asian isolates; group IV included Japanese isolates and an eastern Russian isolate. Groups I, II and III corresponded to Borrelia burgdorferi, $B$. garinii and group VS461, respectively. The RFLPs of Japanese isolates were rather divergent and some of the isolates were quite distinct from the USA and European isolates. RFLP analysis of the rRNA genes and flanking regions, using $r r l$ gene probes as we reported here, may be useful in the taxonomic study of Borrelia.
\end{abstract}

\section{Introduction}

Since the first isolation of Borrelia burgdorferi (Burgdorfer et al., 1982; Johnson et al., 1984), a large number of $B$. burgdorferi isolates have been obtained from patients, animal reservoirs and tick vectors from various geographic areas of the world (Hughes \& Johnson, 1990; Hughes et al., 1992; Nakao et al., 1992; Postic et al., 1990). These organisms have been characterized from the immunological, biochemical and molecular biological aspects (Barbour \& Hayes, 1986; Barbour \& Garon, 1987; Bergström et al., 1989; Howe et al., 1985; Hyde \& Johnson, 1984), and now the species $B$. burgdorferi is regarded as a heterogeneous one which encompasses diverse isolates from geographically distinct areas. Recently, on the basis of DNA homology, specific rRNA gene restriction pattern and protein electrophoresis patterns, three genospecies for the strains of $B$. burgdorferi have been proposed. Two of them are named B. burgdorferi and B. garinii, and the third genospecies is referred to as 'group VS461' (Baranton et al., 1992).

A number of reports have appeared on the characterization of a variety of genera by using restriction fragment

\footnotetext{
* Author for correspondence. Tel. 81-849-36-2111 ext. 5216; fax 81849-36-2024.

Abbreviations: $r r s, r r l, r r f, 16 \mathrm{~S}, 23 \mathrm{~S}$ and $5 \mathrm{~S}$ rRNA genes, respectively; RFLP, for restriction fragment length polymorphism.
}

length polymorphism (RFLP) of the rRNA operons (Grimont \& Grimont, 1986; Luccini \& Altwegg, 1992; Smith \& Callihan, 1992; Stull et al., 1988). Typically, these RFLPs are identified by genomic Southern hybridization with radiolabelled probe(s), and these procedures are most successful for characterizing the bacterial species and are also useful in identifying geographical isolates and for epidemiological studies.

We are studying the organization of the genes coding for the rRNAs of spirochaetes. Organization and transcription of genes for rRNA have been highly conserved among prokaryotes because the synthesis of rRNA is an essential process in the growth of any organism (Nomura \& Morgan, 1977; Nomura et al., 1984). The genes for the rRNAs are, in general, organized into operons with the order of $r r s-r r l-r r f$; the operon is transcribed as a single precursor RNA, and is processed to yield the mature rRNA molecules (Srivastava \& Schlessinger, 1990). In contrast, $B$. burgdorferi has a unique organization of rRNA genes. The $r r s$ gene is physically separated from the $r r l / r r f$ gene cluster and specifically a $3 \cdot 2 \mathrm{~kb}$ direct tandem duplication of $\mathrm{rrl} / \mathrm{rrf}$ has been detected (Davidson et al., 1992; Fukunaga et al., 1992; Fukunaga \& Sohnaka, 1992; Schwartz et al., 1992). On the basis of these findings, preliminary observations of RFLP associated with the $r r l / r r f$ tandem gene cluster have been reported (Schwartz et al., 1992). An RFLP analysis using tandem repetition could be 
Table 1. Bacterial strains, origins and genotypes.

\begin{tabular}{|c|c|c|c|c|c|}
\hline Strain or Isolate & Origin & Genospecies* & $\begin{array}{l}\text { Geographic } \\
\text { location }\end{array}$ & Provided by: $\dagger$ & RFLP pattern \\
\hline B31 & I. dammini & B. burgdorferi & USA & ATCC 35210 & I \\
\hline 297 & Patient & B. burgdorferi & USA & Y. Yanagihara & I \\
\hline CT-1 & I. dammini & B. burgdorferi & USA & R. C. Johnson & I \\
\hline TXGW & Patient & & USA & R. C. Johnson & I \\
\hline PAL & Patient & & USA & R. C. Johnson & I \\
\hline ALA & I. pacificus & & USA & R. C. Johnson & I \\
\hline IPS & I. pacificus & & USA & R. C. Johnson & I \\
\hline MMT1 & I. dammini & & USA & R. C. Johnson & I \\
\hline MM1 & I. dammini & & USA & R. C. Johnson & I \\
\hline $\mathrm{NCH}-1$ & Patient & & USA & R. C. Johnson & I \\
\hline 20006 & 1. ricinus & B. burgdorferi & France & Y. Yanagihara & I \\
\hline 212 & I. ricinus & B. burgdorferi & France & G. Baranton & I \\
\hline IP1 & Patient & B. burgdorferi & France & G. Baranton & I \\
\hline IP2 & Patient & B. burgdorferi & France & Y. Yanagihara & I \\
\hline IP3 & Patient & B. burgdorferi & France & G. Baranton & I \\
\hline SV1 & I. ricinus & B. burgdorferi & France & G. Baranton & I \\
\hline SV3 & I. ricinus & B. burgdorferi & France & G. Baranton & I \\
\hline GeHo & Patient & & Germany & G. Baranton & I \\
\hline $\mathrm{P} / \mathrm{Bi}$ & Patient & B. garinii & Germany & Y. Yanagihara & II-1 \\
\hline N34 & I. ricinus & B. garinii & Germany & Y. Yanagihara & II-1 \\
\hline A & Tick & & Germany & G. Baranton & II-1 \\
\hline K48 & I. ricinus & & Germany & R. C. Johnson & II-I \\
\hline G25 & I. ricinus & B. garinii & Sweden & Y. Yanagihara & II-I \\
\hline SV2 & I. ricinus & & France & G. Baranton & II-I \\
\hline PD89 & Patient & & China & R. C. Johnson & II-I \\
\hline $\operatorname{Ir} 210$ & I. ricinus & & Russia & R. C. Johnson & II-I \\
\hline 153 & I. ricinus & B. garinii & France & G. Baranton & II-2 \\
\hline 2/B45 & I. ricinus & & Germany & Y. Yanagihara & II-3 \\
\hline HP1 & I. persulcatus & & Japan & N. Sato & II-4 \\
\hline HP3 & I. persulcatus & B. garinii & Japan & N. Sato & II-4 \\
\hline Sika2 & I. persulcatus & & Japan & E. Isogai & II-4 \\
\hline HT18 & I. persulcatus & & Japan & M. Nakao & II-4 \\
\hline NT23 & I. persulcatus & & Japan & M. Nakao & II-4 \\
\hline HP13 & I. persulcatus & & Japan & N. Sato & II-5 \\
\hline NP5 & I. persulcatus & & Japan & Y. Yanagihara & II-6 \\
\hline NP10 & I. persulcatus & & Japan & Y. Yanagihara & II-6 \\
\hline Ip90 & I. persulcatus & B. garinii & Russia & G. Baranton & II-7 \\
\hline $\mathrm{BO} 23$ & Patient & VS461 & Germany & G. Baranton & III-1 \\
\hline M7 & I. persulcatus & & China & R. C. Johnson & III-1 \\
\hline ASA-1 & Rodent & & Japan & M. Nakao & III-1 \\
\hline HP6 & I. persulcatus & & Japan & Y. Yanagihara & III-1 \\
\hline $\mathrm{IpF}$ & I. persulcatus & & Japan & M. Nakao & III-2 \\
\hline Iper3(Ip3) & I. ricinus & VS461 & Russia & G. Baranton & III-3 \\
\hline UMO1 & Patient & VS461 & Sweden & G. Baranton & III-3 \\
\hline SMS1 & Patient & & Sweden & Y. Yanagihara & III-3 \\
\hline PGau & Patient & VS461 & Germany & G. Baranton & III-3 \\
\hline NT28 & I. persulcatus & & Japan & M. Nakao & III-3 \\
\hline Ip89 & I. persulcatus & & Russia & R. C. Johnson & IV-1 \\
\hline NT24 & I. persulcatus & & Japan & M. Nakao & IV-1 \\
\hline NT29 & I. persulcatus & & Japan & M. Nakao & IV-1 \\
\hline HT67 & I. persulcatus & & Japan & M. Nakao & IV -2 \\
\hline
\end{tabular}

* Genospecies proposed by Baranton et al. (1992)

† Addresses: Y. Yanagihara, Dept of Microbiology, Univ. Shizuoka, Japan; R. C. Johnson, Dept of Microbiology, Univ. Minnesota, USA; G. Baranton, Institut Pasteur, France; N. Sato, Dept Epidemiology, Hokkaido Institute of Public Health, Japan; E. Isogai, Dept of Preventive Dentistry, Higashi Nihon Gakuen University, Japan; M. Nakao, Dept of Parasitology, Asahikawa Medical College, Japan.

useful in identifying closely related isolates of the same species.

We report here a grouping of Borrelia strains isolated from Europe, the USA and Asia. The results of this analysis of about 50 isolates indicate that the European and USA isolates can be divided into three distinct RFLP groups. RFLP patterns of the Japanese isolates are more divergent than the USA or European isolates. 
Some of the Japanese isolates are classified into groups II and III, but the other isolates do not belong to these groups.

\section{Methods}

Bacterial strains and medium. Strain designations and origins of the Borrelia isolates used in the present study are given in Table 1. All organisms were kept at $-80^{\circ} \mathrm{C}$ and were routinely grown in BSKII medium (Barbour, 1984). Cells were collected, washed by centrifugation and stored at $-80{ }^{\circ} \mathrm{C}$ until further use. Escherichia coli $\mathrm{HB} 101$ was used as the recipient of the recombinant plasmid DNA.

Preparation of DNA and genomic hybridization. Total cellular DNA was extracted by the method of Fukunaga \& Mifuchi (1989a). DNAs were digested with the enzymes indicated and electrophoresed in agarose gels. Genomic DNA fragments in an agarose gel were stained with ethidium bromide, photographed and transferred to a nylon membrane (Fukunaga \& Mifuchi, 1989a). Southern hybridization was performed as described previously (Fukunaga et al., 1992).

Probes used in this study. We used two types of probe in this study as indicated in Fig. 1. The plasmid containing the NheI-PstI fragment (about 200 bp of the $5^{\prime}$ part of gene $r r l$ ) or the StyI fragment (about $300 \mathrm{bp}$ of the $3^{\prime}$ part of $\mathrm{rrl}$ ) was made by appropriate restriction enzyme digestion, blunting and a self-ligation of deletion kit. The plasmid DNA was extracted and purified as previously described (Fukunaga \& Mifuchi, 1989b) and subjected to polymerase chain reaction (PCR) amplification in $50 \mu \mathrm{l}$ of a solution containing $10 \mathrm{mmol}$ Tris/ $\mathrm{HCl}(\mathrm{pH} 8.3), 1.5 \mathrm{mmol} \mathrm{MgCl}_{2}, 50 \mathrm{mmol} \mathrm{KCl}, 0.1 \%$ Triton X-100, $200 \mu \mathrm{mol}$ each of dATP, dGTP, dCTP and dTTP, 2.5 units of Taq polymerase (Takara Shuzo Co., Kyoto, Japan), $0 \cdot 4 \mu \mathrm{mol}$ each of universal primers (M4 and RV) and $1 \mathrm{ng}$ of plasmid DNA. The reaction was carried out for 30 cycles in a DNA thermal cycler (ATTO Zymoreactor, ATTO Corp., Tokyo, Japan), with a profile of denaturation at $94{ }^{\circ} \mathrm{C}$ for $30 \mathrm{~s}$, annealing at $45^{\circ} \mathrm{C}$ for $20 \mathrm{~s}$, and extension at $72{ }^{\circ} \mathrm{C}$ for $90 \mathrm{~s}$. Each PCR product $(5 \mu l$ sample of the reaction mixture) was labelled by using deoxycytidine $5^{\prime}-[\alpha-$ $\left.{ }^{32} \mathrm{P}\right]$ triphosphate $\left(\left[\alpha^{-32} \mathrm{P}\right] \mathrm{dCTP}\right)\left[6000 \mathrm{Ci} \mathrm{mmol}^{-1}\left(222 \mathrm{TBq} \mathrm{mmol}^{-1}\right)\right.$; Amersham] and a random primer labelling kit (Takara Shuzo), and used as a genomic hybridization probe.

\section{Results}

\section{Genomic Southern hybridization}

Fifty-one Borrelia isolates were obtained from ticks of the the family Ixodidae, rodents and patients from various geographic locations. Genomic DNA was

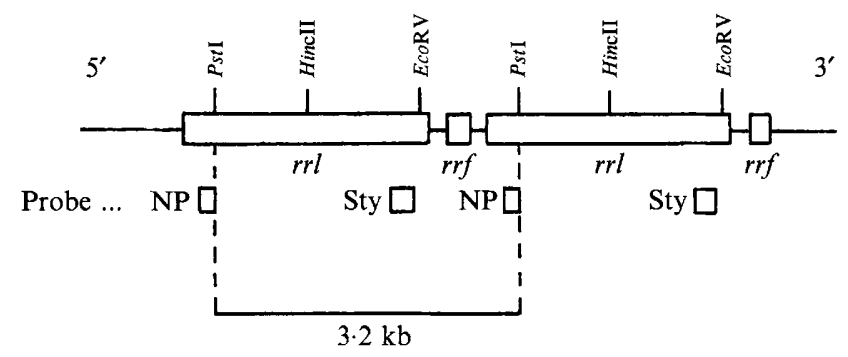

Fig. 1. Partial restriction map of the $r r l / r r f$ gene cluster for $B$. burgdorferi strain B31. The location of the genes and probes ('NP', 'Sty') used in this study are indicated. isolated from these isolates and digested with $E c o \mathrm{RV}$, $H i n c I I$ or PstI. These enzymes were chosen on the basis of our previous studies on ribosomal RNA gene organization of $B$. burgdorferi (Fukunaga \& Sohnaka, 1992; Fukunaga et al., 1992). DNA digests were separated in an agarose gel, blotted and hybridized with the probe. EcoRV cleaves inside the $r r l$ sequence at a single site near the $3^{\prime}$ end, HincII cleaves at the middle, and PstI cleaves near the $5^{\prime}$ end (Fig. 1). Genomic Southern hybridization yielded patterns, usually sharing a common $3.2 \mathrm{~kb}$ fragment. As shown in Fig. 1, a $3.2 \mathrm{~kb}$ band represents a fragment which begins at the enzyme cleavage site in the first $r r l$ sequence, includes the first $r r f$ sequence, and ends at the cleavage site in the second copy of the $r r l$ sequence. A second band which comprises the remainder of the second $r r l$ sequence, the second $r r f$ sequence, and the downstream region until the next restriction site was detected by using probe 'Sty'. Using probe 'NP' revealed a second band consisting of the remainder of the first $r r l$ sequence and the upstream region until the next enzyme cleavage site.

The results of one such experiment using the 'NP' probe are shown in Fig. 2. The results presented in Fig. 2 (a) reveal two bands, the $3.2 \mathrm{~kb}$ band being common (except in strain BO23). Five isolates (B31, MMT1, MM1, NCH-1 and IP3) gave a $5 \cdot 1 \mathrm{~kb}$ second band which contains the $5^{\prime}$ half of the first $r r l$ sequence and the upstream region until the next HincII site. Iper3(Ip3) and SMS1 yielded a $3.7 \mathrm{~kb}$ second band but $\mathrm{BO} 23$ gave a single $5.0 \mathrm{~kb}$ band, which indicates that there is no $H i n c I I$ restriction site of the $r r l$ sequence for $\mathrm{BO} 23$. The genomic Southern hybridization of Pst I digests is shown in Fig. 2(b,c). By using probe 'NP', four Japanese isolates (HT18, Sika2, HP1 and HP3) and two German isolates $(\mathrm{P} / \mathrm{Bi}$ and $\mathrm{N} 34)$ presented contrasting profiles. The Japanese isolates have a PstI site near the $5^{\prime}$ region of the $r r l$ sequence but the PstI site in the German isolates is distant from the $r r l$ genes. Two other isolates (Ip90 and 2/B45) have no PstI site in the $r r l$ sequence.

\section{Schematic representation of RFLP for Borrelia isolates}

The results obtained with the 'NP' and 'Sty' probes are summarized and presented schematically in Fig. 3, and the RFLP patterns exhibited by the 51 Borrelia isolates are indicated in Table 1. Four major RFLP groups were found as shown in Table 1. All of the isolates classified into group I, including the B. burgdorferi $\mathrm{B} 31$ type strain, produced an identical RFLP pattern, and the other groups had minor differences in the sizes of some fragments.

EcoRV or HincII digests of the isolates of group II revealed a high degree of similarity among these isolates of diverse geographic origin, while the PstI digests 

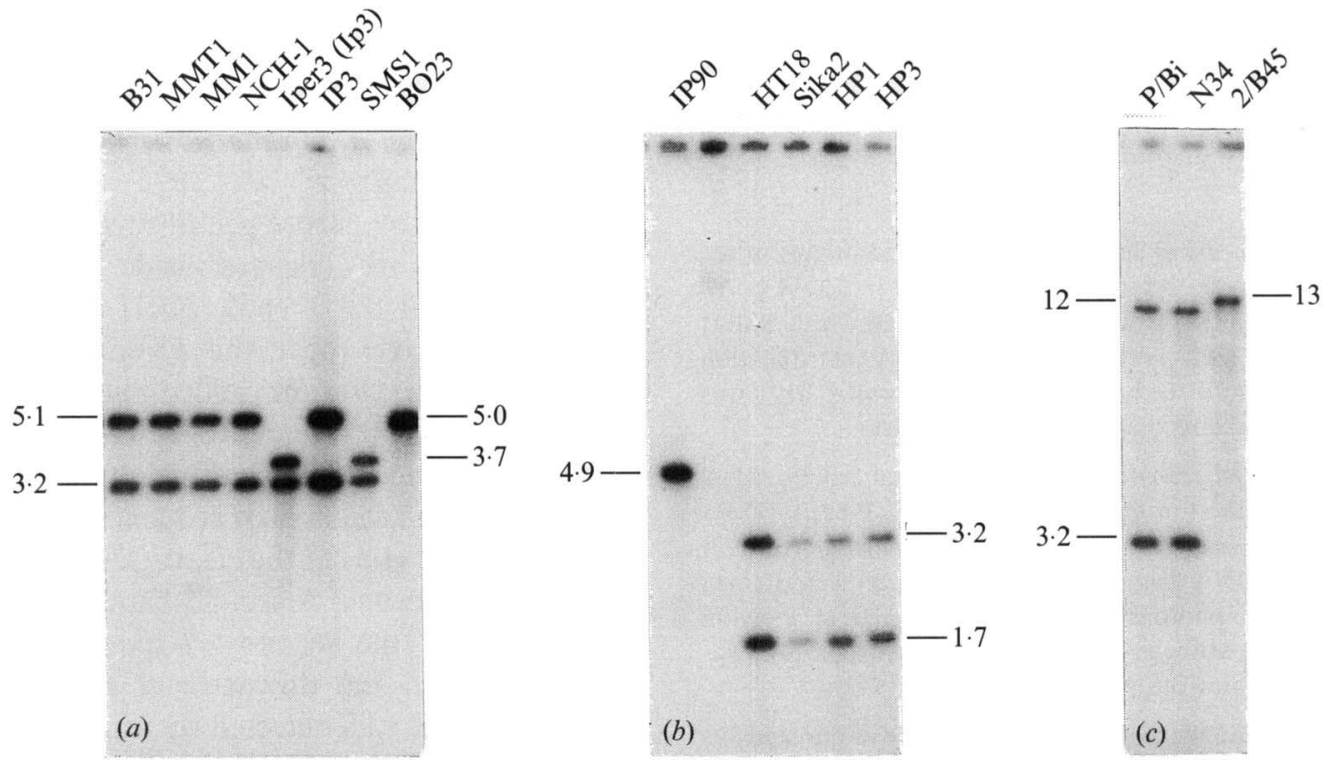

Fig. 2. Genomic Southern hybridization of Borrelia isolates. Genomic DNA from isolates as indicated in the figure was digested with HincII $(a)$ or PstI $(b, c)$, electrophoresed, blotted and hybridized with the 'NP' probe. All other experimental conditions are described in Methods.



Fig. 3(a)

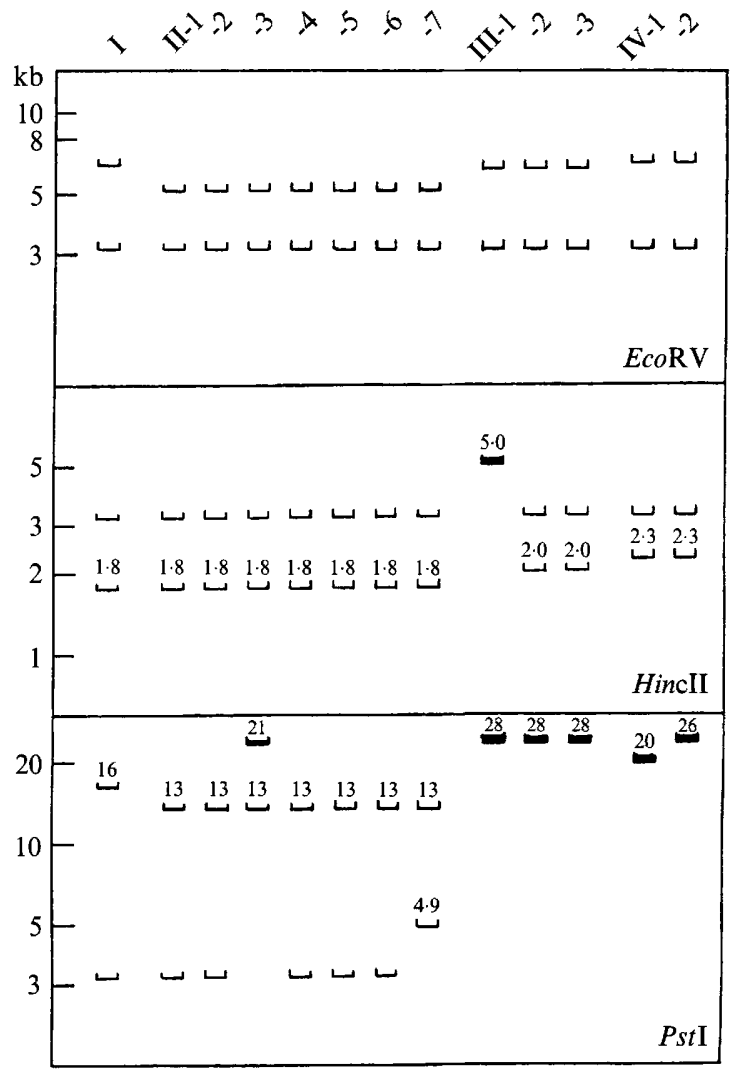

Fig. 3(b)

Fig. 3. Schematic representation of the hybridization patterns with the probe. (a) Genomic DNA was digested with EcoRV, HinclI and PstI and hybridized with the 'NP' probe. (b) Genomic digests were probed with 'Sty'. All results are given as averages of size estimates obtained from at least two independent Southern blots. The isolates whose fragment sizes were close together were electrophoresed side by side and the exact size was measured. The thick lines represent doublet bands. The names of strains included in each RFLP type are shown in Table 1. 
showed different polymorphic bands (Fig. $3 a, b$ ). Of the 10 isolates belonging to group III, four lacked a HincII cleavage site in the $r r l$ sequence while all isolates displayed an identical band with EcoRV or Pst $\mathrm{I}$ digestion. The isolates of group IV shared a common pattern with enzyme digestion by EcoRV and HincII but not PstI. In the case of EcoRV digestion, both probes showed the same upstream EcoRV cleavage site. All the isolates share a common $3.2 \mathrm{~kb}$ band with $E c o \mathrm{RV}$ digestion, and the sizes of the second band fell into three different groups $(6.5 \mathrm{~kb}, 6.3 \mathrm{~kb}$ and $5.2 \mathrm{~kb})$. Similar results were obtained with the EcoRV or HincII digests of the isolates of group I and IV. The most consistent difference between groups I and IV was the lack of the PstI site in all isolates from group IV. The group III isolates and some isolates of group II also lack the PstI site in the $r r l$ sequence. The isolates of group I and II were clearly differentiated by $E c o \mathrm{RV}$ digestion.

\section{Discussion}

A number of Borrelia isolates have been obtained from diverse geographic locations. Many Borrelia isolates have been examined by using monoclonal antibodies (Adam et al., 1991; Barbour \& Hayes, 1986; Barbour et al., 1985), plasmid profile analysis (Barbour \& Garon, 1987; Howe et al., 1985; Hughes et al., 1992; Schwan et al., 1988) and DNA restriction pattern analysis (Hughes et al., 1992; LeFebvre et al., 1989). RFLP analysis of rRNA genes has several advantages because of their stability, while proteins may not be stably expressed. In fact, determination of rRNA gene RFLP (ribotyping) was previously used successfully in molecular epidemiology to differentiate various Borrelia isolates (Baranton et al., 1992; Postic et al., 1990; Schwartz et al., 1992). The ribotyping has been used to differentiate Borrelia isolates at the level of genetic species. Baranton et al., (1992) proposed three genospecies: I, B. burgdorferi sensu stricto; II, B. garinii sp. nov.; and III, group VS461.

We have reported direct tandem repeat of $r r l / r r f$ sequences in B. burgdorferi strain B31 (Fukunaga \& Sohnaka, 1992). It was of interest to determine whether there is unique rRNA gene organization in other Borrelia isolates, which could be useful in classifying closely related isolates. Genomic DNA was extracted from 51 different Borrelia isolates, digested with EcoRV, HincII or Pst $\mathrm{I}$, electrophoresed, blotted, and probed with two specific types of $r r l$ sequence, 'NP' and 'Sty'. The results revealed that all Borrelia isolates contain two sets of $r r l / r r f$ sequence, and four different RFLP groups were present. Group I comprised all the USA isolates and many European isolates. Group II and group III consisted of isolates obtained from Europe and Asia.
Group IV contained Japanese isolates and a Russian Asia isolate. Groups I, II and III corresponded to $B$. burgdorferi, $B$. garinii and group VS461, respectively, as stated by Baranton et al. (1992).

In contrast to group I, the isolates belonging to group II showed diverse RFLP patterns with PstI or HincII digestion. By using probe 'NP', all the Japanese isolates (group II-4, 5, and 6) showed a pattern distinct from that of the isolates from other geographic locations. It seemed possible, therefore, that this group would form a distinct subset of the species. With HincII digests of group III isolates, quite characteristic patterns were obtained. Group III (group VS461) might be divided into at least two subgroups [group III-1 and group III-3, strain IPF: group III-2 exhibiting both fragments characteristic of group III-1 $(5.0 \mathrm{~kb})$ and III-3 $(3.2 \mathrm{~kb})]$. The isolates that belonged to group IV, including a Russian isolate (Ip89, isolated from I. persulcatus ticks in Khabarovsk territory), showed an RFLP pattern distinct from that of any other groups.

Our studies indicate that RFLP analysis for tandem duplication of rRNA genes and flanking regions in Borrelia species by using $r r l$ gene probes ('NP' and 'Sty') provides a simple and useful tool for determination of genetic relatedness between different Borrelia isolates. We are now applying this technique in an epidemiological study of Japanese Borrelia isolates from various sources.

We thank Drs Guy Baranton, Russell C. Johnson, Emiko Isogai, Nanao Sato, Minoru Nakao and Kenji Miyamoto for supplying Borrelia isolates, and Drs. Toshiyuki Masuzawa and Minoru Nakao for useful discussion. M.F. thanks Professor Ichiji Mifuchi for his constant encouragement.

\section{References}

Adam, T., Gassman, G. S., Rasiah, C. \& Göbel, U. B. (1991). Phenotypic and genotypic analysis of $B$. burgdorferi isolates from various sources. Infection and Immunity 59, 2579-2585.

Baranton, G., Postic, D., Saint Girons, I., Boerlin, P., Piffaretti, J. C., Assous, M. \& Grimont, P. A. D. (1992). Delineation of Borrelia burgdorferi sensu stricto, Borrelia garinii sp. nov., and group VS461 associated with Lyme borreliosis. International Journal of Systematic Bacteriology 42, 378-383.

BARBour, A. G. (1984). Isolation and cultivation of Lyme disease spirochetes. Yale Journal of Biology and Medicine 57, 521-525.

Barbour, A. G. \& Garon, C. F. (1987). Linear plasmids of the bacterium Borrelia burgdorferi have covalently closed ends. Science 237, 409-411

Barbour, A. G. \& HaYes, S. F. (1986). Biology of Borrelia species. Microbiological Reviews 50, 381-400.

Barbour, A. G., Heiland, R. A. \& Howe, T. R. (1985). Heterogeneity of major proteins in Lyme disease Borrelia: a molecular analysis of North American and European isolates. Journal of Infectious Diseases 152, 478-484.

Bergström, S., Bundoc, V. G. \& Barbour, A. G. (1989). Molecular analysis of linear plasmid-encoded major surface proteins, OspA and OspB, of the Lyme disease spirochete Borrelia burgdorferi. Molecular Microbiology 3, 478-486.

Burgdorfer, W., Barbour, A. G., Hayes, S. F., Benach, J. L., Grunwaldt, E. \& Davis, J. P. (1982). Lyme disease - a tick borne spirochetosis? Sciences 216, 1317-1319. 
Davidson, B. E., MacDougall, J. \& Saint Girons, I. (1992). Physical maps of the linear chromosome of the bacterium Borrelia burgdorferi 212, a causative agent of Lyme disease, and localization of rRNA genes. Journal of Bacteriology 174, 3766-3774.

FukUNAGA, M. \& MifuCHI, I. (1989a). The number of large ribosomal RNA genes in Leptospira interrogans and Leptospira biflexa. Microbiology and Immunology 33, 459-466.

FukUnaGa, M. \& MifuChI, I. (1989b). Unique organization of Leptospira interrogans rRNA genes. Journal of Bacteriology 171, 5763-5767.

FukunaGa, M. \& Sohnaka, M. (1992). Tandem repeat of the 23 S and 5S ribosomal RNA genes in Borrelia burgdorferi, the etiological agent of Lyme disease. Biochemical and Biophysical Research Communications 183, 952-957.

Fukunaga, M., Yanagihara, Y. \& Sohnaka, M. (1992). The 23S/5S ribosomal RNA genes $(r r l / r r f)$ are separate from the $16 \mathrm{~S}$ ribosomal RNA gene (rrs) in Borrelia burgdorferi, the aetiological agent of Lyme disease. Journal of General Microbiology 138, 871-877.

Grimont, F. \& Grimont, P. A. D. (1986). Ribosomal ribonucleic acid gene restriction patterns as potential taxonomic tools. Annales de l'Institut Pasteur/Microbiology 137B, 165-175.

Howe, T. R., MaYer, L. W. \& Barbour, A. G. (1985). A single recombination plasmid expressing two major surface proteins of the Lyme disease spirochete. Science 227, 645-646.

Hughes, C. A. N. \& Johnson, R. C. (1990). Methylated DNA in Borrelia species. Journal of Bacteriology 172, 6602-6604.

Hughes, C. A. N., Kodner, C. B. \& Johnson, R. C. (1992). DNA analysis of Borrelia burgdorferi $\mathrm{NCH}-1$, the first northcentral U.S. human Lyme disease isolate. Journal of Clinical Microbiology 30, 698-703.

Hyde, F. W. \& Johnson, R. C. (1984). Genetic relationship of Lyme disease spirochetes to Borrelia, Treponema and Leptospira. Journal of Clinical Microbiology 20, 151-154.

Johnson, R. C., Hyde, F. W., SChMidt, G. P. \& Brenner, D. J. (1984). Borrelia burgdorferi sp. nov.: etiological agent of Lyme disease. International Journal of Systematic Bacteriology 34, 496-497.
LeFebvre, R. B., Perng, G. C. \& Johnson, R. C. (1989). Characterization of Borrelia burgdorferi isolates by restriction endonuclease analysis and DNA hybridization. Journal of Clinical Microbiology 27, 636-639.

Luccini, G. M. \& AltwegG, M. (1992). rRNA gene restriction patterns as taxonomic tools for the genus Aeromonas. International Journal of Systematic Bacteriology 42, 384-389.

Nakao, M., MiYamoto, K., Uchikawa, K. \& Fujta, H. (1992). Characterization of Borrelia burgdorferi isolated from Ixodes persulcatus and Ixodes ovatus ticks in Japan. American Journal of Tropical Medicine and Hygiene 47, 505-511.

Nomura, M., Gourse, R. \& Baughman, G. (1984). Regulation of the synthesis of ribosomes and ribosomal components. Annual Review of Biochemistry 53, 75-117.

Nomura, M. \& Morgan, E. A. (1977). Genetics of bacterial ribosomes. Annual Review of Genetics 11, 297-347.

Postic, D., Edlinger, C., Richaud, C., Grimont, F., Dufresne, Y., Perolat, P., Baranton, G. \& Grimont, P. A. D. (1990). Two genomic species in Borrelia burgdorferi. Research in Microbiology 141, 465-475.

Schwan, T. G., Burgdorfer, W., SchrumpF, M. E. \& Karstens, R. H. (1988). The urinary bladder, a consistent source of Borrelia burgdorferi in experimentally infected white-footed mice (Peromyscus leucopus). Journal of Clinical Microbiology 26, 893-895.

Schwartz, J. J., Gazumyan, A. \& Schwartz, I. (1992). rRNA gene organization in the Lyme disease spirochete, Borrelia burgdorferi. Journal of Bacteriology 174, 3757-3765.

Smith, C. J. \& Callihan, D. R. (1992). Analysis of rRNA restriction fragment length polymorphism from Bacteroides spp. and Bacteroides fragilis isolates associated with diarrhea in humans and animals. Journal of Clinical Microbiology 30, 806-812.

Srivastava, A. K. \& Schlessinger, D. (1990). Mechanism and regulation of bacterial ribosomal RNA processing. Annual Review of Microbiology 44, 105-129.

Stull, T. L., Lipuma, J. J. \& EdLind, T. D. (1988). A broad spectrum probe for molecular epidemiology of bacteria: ribosomal RNA. Journal of Infectious Diseases 157, 280-286. 